\title{
The Role of Exercise as a Treatment and Preventive Strategy during Covid-19 Pandemic
}

\author{
Covid-19 Salgınında Egzersizin Bir Tedavi ve Önleyici \\ Strateji Olarak Rolü
}

\begin{abstract}
On 11 March 2020, World Health Organization has made the assessment that COVID-19 can be characterized as a pandemic. COVID-19 is a usually self-limited infection but it can be present a severe and fatal disease in patients with comorbitidies and the elderly. The characteristics of the virus and general health condition of the host determine disease progression. Scientists have been investigating on the pathophysiology of this disease, diagnostic tools, effective treatment protocols, and the development a vaccine. Preventive strategies are as important as the treatment modalities. This review focuses on the pathophysiological mechanisms of COVID-19, in addition to the roles of exercise in the immunomodulatory mechanisms, host defense systems, and also prevention and treatment of COVID-19. Exercise exerts many important effects such as immunomodulation, augmented defense system on the immune system via mainly muscle derived myokines and increased cardiorespiratory endurance. COVID-19 pandemic once again demonstrated the importance of prophylactic approaches such as healthy life, maintaining and strengthening of health, and immune system modulation. This pandemic may start a period in which humanity prioritizes healthy living principles, functional foods, maintaining health and welfare approaches, and increased effort to develop and maintain them.
\end{abstract}

Keywords: Covid-19 pandemic; pathophysiology; immune system; exercise; myokines

\section{Öz}

11 Mart 2020'de Dünya Sağlık Örgütü (WHO) COVID-19 küresel salgınını ilan etti. COVID-19 genellikle kendi kendini sınırlayan bir enfeksiyon olduğu halde yașıllarda ve komorbiditesi olan bireylerde çok daha ciddi ve ölümcül seyretmektedir. Virüsün özellikleri ve konağın genel sağ|ık durumu hastalığın nasıl seyredeceğini belirlemektedir. Bilim adamları bu hastalığın fizyopatolojisini açıklamak, teșhis yöntemlerini, etkili tedavi protokollerini ve așısını geliștirmek için çalışıyorlar. Önleyici stratejiler tedavi yöntemleri kadar önemlidir. Bu derleme COVID-19 fizyopatolojisine, ve egzersizin immünomodülatör mekanizmalarda, konakçı savunma sistemlerinde ve COVID-19'un önlenmesinde ve tedavisindeki rollerine odaklanmaktadır. Egzersiz kardiyopulmoner dayanıkılığı ve kaslardan miyokinlerin üretimini artırarak immün sistemi güçlendirir ve immün yanıtı düzenler. COVID-19 salgını, sağlıkı yașam, sağlığın korunması ve güçlendirilmesi ve bağıșıklık sistemi modülasyonu gibi profilaktik yaklașımların önemini bir kez daha göstermiștir. Bu salgın, insanoğlunun sağlıklı yașam prensiplerini, fonksiyonel gıdaları, sağlığını korumayı ve refah yaklașımlarını daha ön planda tuttuğu, ve bunları geliștirme ve sürdürme çabalarının arttığı bir dönemi bașlatabilir.

Anahtar Sözcükler: Covid-19 pandemisi; fizyopatoloji; immün sistem, egzersiz; myokin

\section{Meltem Yalcin', Elif Kocak², Mehtap Kacar ${ }^{3,4}$}

1 Yeditepe University Graduate School of Health Sciences, Department of Physiology, Istanbul, Turkey

2 Koç University School of Medicine, Istanbul, Turkey

3 Yeditepe University Faculty of Medicine, Department of Physiology, Istanbul, Turkey

${ }^{4}$ Yeditepe University Graduate School of Health Sciences, Department of Pathophysiology, Istanbul, Turkey

Received/Gelis : 04.05.2020 Accepted/Kabul : 22.05.2020

DOI: 10.21673/anadoluklin.731902

Corresponding author/Yazıșma yazarı Mehtap Kacar

Yeditepe University, Faculty of Medicine, Department of Physiology,

34755, Istanbul, Turkey

E-mail: mehtap.kacar@yeditepe.edu.tr

\section{ORCID}

Meltem Yalcin: 0000-0001-8474-6464 Elif Kocak: 0000-0002-0042-0633 Mehtap Kacar: 0000-0002-1572-4787 


\section{INTRODUCTION}

In December 2019, several cases of pneumonia of unknown etiology were detected in Wuhan City, China. On 7 January 2020, Chinese authorities identified the etiology as a new type of coronavirus and named the disease 2019-nCov. As of 20 January 2020, 282 confirmed cases of 2019-nCov have been reported from China, Thailand, Japan, and the Republic of Korea (1) Rapidly spreading, this outbreak has affected hundreds of countries and millions of people in a short period of time. On 11 March 2020, World Health Organization (WHO) has made the assessment that COVID-19 can be characterized as a pandemic (2). As of 2 May 2020, 215 countries were affected from the pandemic, total number of cases were reported as 3.267.184, and total number of deaths were 229.970 (3). Scientists around the globe are working to control the spread of this disease, to develop faster and more accurate diagnostic tools, to define effective treatment protocols, and to develop a vaccine. Preventive strategies are as important as the treatment modalities and should be addressed promptly.

Typical presentation of COVID-19 is pneumonia and acute respiratory distress syndrome in more severe cases. However, the virus affects many organ systems such as the cardiovascular and urinary system. Like other infectious diseases, characteristics of the virus (virulence, viral load to exposed, infectivity) and general health condition of the host determine disease progression. Course of COVID-19 is much more severe and fatal in patients older than 65 years and in patients with comorbidities. Accordingly, the importance of general wellbeing and healthy aging are understood once more. The concepts of healthy aging, wellness, and wellbeing are studied more and more by many clinicians and researchers every day. To be and to stay healthy, one should follow a certain lifestyle where a balanced diet, regular exercise, staying away from smoking and alcohol abuse, high sleep quality, and effective stress management are key aspects. Among these, exercise is now being accepted as a treatment modality as well. In this review, the role of regular exercise in healthy aging through immunomodulatory mechanisms and host defense systems in viral diseases are assessed, especially regarding prevention and treatment of COVID-19.

\section{A Brief Pathophysiology of Covid-19}

Members of the coronaviridae family are enveloped, positive-sense, single-stranded RNA viruses, which cause respiratory infections in humans. MERS coronavirus (MERS-CoV; Middle East Respiratory Syndrome Coronavirus), SARS coronavirus (SARS-CoV; Severe Acute Respiratory Syndrome Coronavirus), and novel coronavirus (2019-nCoV or SARS-CoV-2) are some members of this family (4).

COVID-19 is classified as a $\beta \mathrm{CoV}$ of group $2 \mathrm{~B}$ by WHO. A common feature of the first cases of COVID-19 detected in Wuhan was that these patients visited a seafood and wet animal market in the city. These patients were most probably exposed to bats, which serve as a large $\mathrm{CoV}$ reservoir. Accordingly, SARSCoV-2 can lead infections in humans, bats, and wild animals. Person-to-person transmission is the main route for spreading COVID-19 infection. An infected person usually transmits viruses via direct contact or through droplets to another person from mucosal surfaces such as throat, nose, and conjunctiva (5).

In most cases COVID-19 causes mild symptoms and patients recover within 10-14 days without specific treatments. Because of this, COVID-19 has been noted as a self-limiting infectious disease. Clinical outcomes of COVID-19 can be listed as following; infected people without symptoms (in adult 1.2\%; under 10 -years old $15.8 \%)$, mild to medium cases $(80.9 \%)$, severe cases (13.8\%), critical cases (4.7\%), and death (2.3\% in all reported cases) (6).

In symptomatic patients, symptoms appear within 2-14 days of exposure. Symptoms vary from mild to severe. Common symptoms are fever, chills, cough, new onset of loss of taste and smell sensation, headache, sore throat, muscle pain, and dyspnea (7).

Additionally, symptoms such as diarrhea, hemoptysis, rhinorrhea, sneezing, sputum productions, and lymphopenia can also be seen. Diagnosis is confirmed by clinical presentation (two or more symptoms) and laboratory tests such as viral test, and computerized tomography of thorax. In thorax CT, ground-glass opacities are seen (5).

During life we are continuously exposed to many microorganisms from the external environment. $\mathrm{Mi}$ croorganisms can enter the human body from different ways such as mucosal surfaces, skin, blood. The 
nonspecific and specific defense mechanisms protect body from these invaders. The mucosal and epithelial integrity and secretions, surface IgA secretion, inflammatory response, innate and adaptive immune system cells play important roles in this process. Many factors can lead to disruptions in these mechanisms and provide a tendency for infectious diseases. There are two important factors in the development of infectious diseases: features of the virus and defense mechanisms of the host. Viruses lead to infection via direct cell damage and the host immune system respond to this damage by immunopathogenesis. The balance or modulation of immune responses determine effective immune response to clearance of viruses. When the immune response is exaggerated or sustained, this exaggerated response leads to severe damage of respiratory tract or affected area. If immune response is weak or ineffective, the virus cannot be eliminated and infectious disease occurs (8) .

After exposed to SARS-CoV-2, viruses reach mucosal surfaces especially throat, nasal mucosa and conjunctiva. If SARS-CoV-2 copes with host defense mechanism, it begins to multiply by active replication in the upper respiratory tissues. SARS-CoV-2 has high infectivity and binds angiotensin-converting enzyme 2 (ACE2) in order to enter the cells (9).

After inhalation of the virus, asymptomatic stage starts, and its duration takes 1-2 days. SARS-CoV-2 probably attaches to epithelial cells in the nasal cavity and viral replication begins. It has been demonstrated that SARS-CoV primarily infects the ciliated cells of conducting airways in vitro (10). For this reason, nasal swabs should be preferred for diagnosis, it can be more sensitive than throat swabs. At this stage, innate immune response starts. If this response is effective, it limits viral propagation. If it is ineffective, the number of virus increases, and viruses reach upper airway and conducting airway cells within next few days (10). Viral replication continue in the lower respiratory tract cells, and when virus enter the circulation, viremia starts. SARS-CoV-2 viruses attack many tissues and organs that have ACE2 receptors like kidneys, and heart. The severity of viremia is associated with deterioration of clinical presentation (9).

ACE2 is a monocarboxypeptidase enzyme, and is responsible for degradation of angiotensin I and II to produce Ang1-7 and Ang 1-9. In addition, ACE2 is a functional SARS-CoV receptor and an amino acid transporter (11). ACE2 is commonly expressed as a type I membrane protein in many tissues and organs such as lungs, heart, kidney, testes, brain, vascular system, cardiomyocytes, coronary vascular endothelium, cardiac fibroblasts. It plays protective roles in these organs and tissues in physiological conditions (11).

SARS-CoV-2 binds to the extracellular domain of ACE2 via its SPIKE (S protein) protein. The host protease TMPRSS2 leads to cleavage of the $S$ protein to produce the S1 and S2 subunits. This step is critical for attachment of the virus to host cell membrane, which occurs due to the generation of S2 subunit. After attachment, virus enters pulmonary epithelial cells by ACE2 mediated endocytosis. The S1 subunit of viral protein provides the greater virulence and higher affinity for ACE2. The increased ACE2 internalization causes decreased levels of ACE2 in the tissues. This reduction is responsible for loss of useful and protective effects of ACE2 on the heart, lungs and other tissues and dysfunction of the renin-angiotensin system (RAS). The decreased effectiveness of ACE2 may be associated with severity of clinical presentation such as heart failure, shock, respiratory failure (12).

The strong and rapid viral replication in the pulmonary epithelial and endothelial cells may lead severe immune response characterized by aberrant production of pro-inflammatory cytokines and chemokines. The exaggerated inflammatory response may result in severe tissue damage, increased capillary permeability, and tissue edema in the pulmonary system. Absence of ACE2 function in respiratory system may be associated with acute lung injury. It has been observed that immune dysfunction, exaggerated inflammatory response, and cytokine storm, causes reduced peripheral CD4 and CD8 T cell counts, and increased proinflammatory CD4 T cells and cytotoxic granules in CD8 T cells (6). The other source of proinflammatory cytokines is mast cells that are localized on the mucosal surface and connective tissue of the respiratory system. Mast cells are activated by viruses, bacteria and fungi via their toll-like receptors (TLRs). The increased levels of proinflammatory cytokines such as IL-1, IL-6, TNF- $\alpha$ are resulted from activation of mast cells. On the other hand, mast cells produce and secrete some 
mediators such as histamine, prostaglandin-D2, leukotriene-C4 that are responsible for bronchoconstriction during respiratory system infection. SARS-CoV-2 may lead to exaggerated activation of mast cells. This activation may contribute to cytokine storm and severe lung inflammation during COVID-19 (13).

On the other hand, researchers recently demonstrated ACE2 mediated internalization of SARS$\mathrm{CoV}-2$ in the various cranial nerves and the presence of virus in the brain. Viruses probably reach to brain via cranial nerves. This important finding can explain why some patients present with loss of taste and smell sensation, syncope, or balance problems as COVID-19 symptoms. However, the decreased levels of ACE2 in the extracellular compartments cause lack of useful ACE2 effects in the central nervous system. The cardiovascular and respiratory control centers cannot function properly, and for this reason the regulation of blood pressure and respiration is disrupted. Generalized endothelial damage, exaggerated inflammation, and disorganization of amino acid transport occur in many tissues. After COVID-19, some chronic diseases including atherosclerosis, diabetes, hypertension can develop in patients (12).

\section{Exercise and COVID-19}

In COVID-19 infection, the status of the host's immunity plays a highly critical role in the response to the virus. Healthy immune system produces effective and proper response which reduces the severity of the disease and recovery time. According to researchers in the field of exercise, immunology and physiology, regular physical activity might be one of the best ways to support the immune system components and also to cope with the risk factors of the COVID-19, as a nonpharmacological, inexpensive, and easily reachable way for individuals when not contraindicated (14). Although there is no scientific relationship between physical activity and COVID-19 yet, it is well-known that the immune system can be modulated by the regular physical activity (15). Epidemiological studies have showed that, in individuals who maintain regular physical activity as an active lifestyle in accordance with the conditions set by WHO (at least 150 minutes per week, moderate to vigorous exercise); incidence of age-related chronic diseases and comorbidities are re- duced, host body response against infections as well as vaccination is improved and basal inflammatory level is decreased (16). It has been demonstrated that physically active individuals show upper respiratory illness symptoms less than sedentary ones $(17,18)$. Regular physical activity might be an effective tool against viral infections like influenza, rhinovirus and herpesviruses since the decreased mortality and incidence rates (19).

Although all age groups are at risk of COVID-19, older people have an increased risk of developing severe illness as a complication of COVID-19 due to ageinduced physiological changes, immune dysregulation with aging (immunosenescence), potential underlying comorbidities (20). Regular moderate-intensity exercise can delay the immunosenescence and risk of infection through mechanisms associated with oxidative stress and immune system regulation (21). Pollock et al (2018) showed that amateur cyclists from old age group (55-79 years old) still had the healthy immune systems like young people (22). Therefore, engaging with regular physical activity is very important for elder populations and they should be encouraged to do it. Children are less likely to be infected in this pandemic according to the reports (23). It has been noted that the moderate-to-high levels of physical activity are associated with lower incidence of infection and illness in children (24).

Leading organizations like WHO recommends multicomponent exercise programs consisting of aerobic and resistance exercise modalities for all age groups (25). It is widely accepted regular moderateintensity aerobic exercise (40-60\% heart rate reserve or $65-75 \%$ of maximal heart rate, 150 minutes/week) such as walking is ideal for reaching the optimal immune health (26). On the other hand, although the direct linkage between the resistance exercise (weight lifting, push-ups, etc.) and immunity is unclear, it has general beneficial effects on wellbeing by improving muscle strength, balance and mobility and also through decreasing psychological distress, and risk factors for chronic diseases (27). It is important to keep in mind that vigorous intensity beyond the recommended range can supress the immunity, some researchers indicate $(28,29)$. Thus, during quarantine times, moderate intensity should be the ideal choice to benefit from the protective role of exercise (21). 
The understanding the ability of regular physical activity effects on the host immunity requires a complex multisystem approach and there are still some undetermined mechanisms behind it. In general, exercise promotes an anti-inflammatory and antioxidant state through multiple mechanisms by recirculation of key immune cells.

During exercise, contracting skeletal muscle fibers express and secrete various cytokines which are called myokines. Myokines are accepted as responsible for the exercise's overall metabolic and anti-inflammatory effects (30). Muscle-derived IL-6 is the first myokine identified and Steensberg et. al. (2003) showed that this myokine mediates the immunomodulatory effects of the exercise by trafficking the immune cells to the infection area, increasing the levels of neutrophils and T-helper cells (31). In addition, IL-6 regulates the postexercise inflammatory status by increasing the plasma levels of anti-inflammatory cytokines such as IL-1Ra and IL-10 and suppressing pro-inflammatory cytokines like TNF- $\alpha$. The exercise-dependent increase in IL-6 is transient and acts as an anti-inflammatory myokine, whereas physical inactivity and sedentary lifestyle choices are associated with a chronic low-level of IL- 6 which can contribute increased and persistent levels of inflammation (32). Some mechanistic studies showed that exercise-induced myokine release is dosedependent and a more pronounced increase is likely to occur during the intense exercise than the moderate one. (33). In addition to IL-6 there are other myokines which can also contribute to proper immune regulation in response to exercise. IL-7 and IL-15 regulate T-cell production and NK-cell homeostasis which can contribute to hosts immune system via muscle contraction in sufficient dose of exercise (34). By this way, exercise can modulate the innate immune function through muscle-derived myokines.

Physical activity augments the immunity with the increase number of immune cells (15). During moderate- and vigorous-intensity aerobic exercise; components of the immune system like immunoglobulins, macrophages, neutrophils, anti-inflammatory cytokines, NK cells, cytotoxic T cells, and immature B cells recirculate with downregulated expression of Toll-like receptor 4 (35). These enhanced immune cells keep guard on the vulnerable areas like upper respiratory tract and lungs and prevent viruses and other invaders. These changes are transient but make the physical activity a strong promoter of immunosurveillance. When the physical activity is conducted regularly, it will lead to decrease in illness incidence by enhancing immunosurveillance (16). When the exercise is regular, the recruitment of the cells such as M1 macrophages and cytotoxic $\mathrm{T}$ cells which are associated with insulin resistance will be limited by decrease the mass of adipose tissue (36).

Exercise can increase the level of immunoglobulins (surface IgA, IgM, IgG) in the mucous membranes. Exercise-induced increase of IgA is particularly critical due to its significant role in the respiratory tract infections (37).

Exercise training decreases the oxidative load of the cells by enhancing anti- oxidative system components like glutathione, catalase, superoxide dismutase, glutathione peroxidase. (35).

Beyond these benefits of regular moderate intensity aerobic exercise, emergent evidence shows another perspective about the potentially relationship between aerobic capacity and COVID-19 infection through respiratory biomechanics. Mohamed and Alawna (2020) suggested that enhanced cardiorespiratory level and aerobic capacity can be preventative and also therapeutic in the respiratory system dysfunctions like acute respiratory distress syndrome through acting as an antibiotic, and antimycotic, improvement of lung tissue elasticity and augmentation of respiratory muscles strength (38). On the other hand, it is well-known that higher cardiorespiratory fitness levels are associated with decreased incidence of chronic diseases like cancer, cardiovascular dysfunctions, type 2 diabetes mellitus, hypertension which are the most reported comorbidities and risk factors with COVID-19 $(34,39)$.

For the patients diagnosed with COVID-19, trainings should be discontinued from the beginning of the acute symptoms until the completion of treatments. During the course of COVID-19, patients can perform pulmonary rehabilitation exercises under the supervision of their doctors in addition to medical treatment modalities (40). In cases recovered from COVID-19 infection, there are some exercise approaches in the physiotherapy and rehabilitation applications which may be needed due to loss of some respiratory and 
physical functions due to prolonged mechanical ventilation and intensive care unit stay, beyond with the multi-system effects of COVID-19. For 6-8 weeks, patients are recommended to perform low-intensity physical activity / exercises ( $<3$ MET, metabolic equation, 3 points for dyspnea and / or fatigue in the modified Borg Scale). The exercise program should be started with relatively simple, gradual functional strengthening exercises without using equipment or body weight. Training intensity should be increased slowly over days $(41,42)$.

Several studies have been done on the effects of exercise on aging, microbiota, or immune system modulation. Woods et al pointed out that in elderly, regularly done moderate-intensity cardiovascular training had anti-inflammatory properties and increased the strength of vaccine-induced immunity against influenza virus. Physical exercise is strongly recommended during the COVID-19 pandemic while paying attention to social distancing and isolation rules. For the patients diagnosed with COVID-19, trainings should be discontinued from the beginning of the acute symptoms until the completion of treatments. Regular physical exercise can be resumed after completion of treatments and full recovery. (43).

The world have been dealing with another pandemic for years besides COVID-19, physical inactivity and it continues to contributes to risk factors of the of COVID-19 (44). Thus, to deal with the negative consequences of isolation and more sedentary lifestyle conditions than before, physical activity should gain importance as a crisis and strongly promoted. The World Health Organization, Centers for Disease Control and Prevention, and other public health counselling organizations encourage individuals to regularly join physical activity to maintain physical and mental health and well-being, when they are not contraindicated and comply with public health and community safety $(45,46)$. Hence exercise is one of the important supportive treatments options and also one of the critical preventive strategies.

\section{CONCLUSION}

Pandemics have always been existed throughout history, have affected humanity from time to time, and led to permanent changes and developments in many different areas of public life. The COVID-19 pandemic once again demonstrated the importance of prophylactic approaches such as healthy life, health protection, strengthening, and immune system modulation. This pandemic will lead to a completely different period in which adopting, developing and maintaining healthy living principles, functional foods, wellness, and wellbeing approaches will be at the forefront. The condition of the immune system of the person and the appropriate response of the immune system, i.e. immune modulation, are very important in the progression of the disease and the success of the treatment. The individual's ideal health level and healthy aging approaches are the most powerful weapons in the fight against not only to COVID-19, but also against to all existing infectious diseases. Future studies should focus on determining and standardizing exercise as a supportive treatment protocol for patients with COVID-19. On the other hand, one of our future goals should be determining and developing specific exercise modalities that support the immune system of healthy individuals at risk. The direct effects of the regular physical activity on the immune system cannot be ignored and the physiological and molecular mechanisms under these effects must be highlighted more by further researches.

The authors received no financial support for the authorship, and/or publication of this article.

Conflict of interest: The authors declare that they have no conflict of interest.

\section{REFERENCES}

1. COVID-19 situation reports [Internet]. World Health Organization. 2020 [cited 2020 May 4]. Available from: https://www.who.int/emergencies/diseases/novelcoronavirus-2019/situation-reports

2. WHO Director-General's opening remarks at the media briefing on COVID-19 - 11 March 2020 [Internet]. World Health Organization. 2020 [cited 2020 May 4]. Available from: https://www.who.int/dg/speeches/detail/who-director-general-s-opening-remarks-at-themedia-briefing-on-covid-19---11-march-2020

3. Coronavirus disease 2019 [Internet]. World Health Organization. 2020 [cited 2020 May 4]. Available from: https://www.who.int/emergencies/diseases/novel- 
coronavirus-2019

4. Coronaviridae - an overview | ScienceDirect Topics [Internet]. [cited 2020 May 4]. Available from: https:// www.sciencedirect.com/topics/neuroscience/coronaviridae

5. Rothan HA, Byrareddy SN. The epidemiology and pathogenesis of coronavirus disease (COVID-19) outbreak. Journal of Autoimmunity. 2020.

6. Jin Y, Yang H, Ji W, Wu W, Chen S, Zhang W, et al. Virology, epidemiology, pathogenesis, and control of covid-19. Viruses. 2020.

7. Symptoms of Coronavirus | CDC [Internet]. Centers for Disease Control and Prevention. 2020 [cited 2020 May 4]. Available from: https://www.cdc.gov/ coronavirus/2019-ncov/symptoms-testing/symptoms. html

8. Newton AH, Cardani A, Braciale TJ. The host immune response in respiratory virus infection: balancing virus clearance and immunopathology. Seminars in Immunopathology. 2016.

9. Cao W, Li T. COVID-19: towards understanding of pathogenesis. Cell Res [Internet]. 2020 May 28 [cited 2020 May 4];30(5):367-9. Available from: http://www. nature.com/articles/s41422-020-0327-4

10. Mason RJ. Pathogenesis of COVID-19 from a cell biologic perspective. The European respiratory journal. 2020.

11. Patel VB, Zhong JC, Grant MB, Oudit GY. Role of the ACE2/angiotensin 1-7 axis of the renin-angiotensin system in heart failure. Vol. 118, Circulation Research. Lippincott Williams and Wilkins; 2016. p. 1313-26.

12. South AM, Diz D, Chappell MC. COVID-19, ACE2 and the Cardiovascular Consequences. American journal of physiology. Heart and circulatory physiology. 2020.

13. Kilinç E, Baranoğlu Y. Mast cell stabilizers as a supportive therapy can contribute to alleviate fatal inflammatory responses and severity of pulmonary complications in COVID-19 infection. Anadolu Klin Tip Bilim Derg. 2020; 25(Supplement 1): 111-118.

14. Richard J. Simpson. Exercise, Immunity and the COVID-19 Pandemic [Internet]. American College of Sports Medicine. 2020 [cited 2020 May 2]. Available from: https://www.acsm.org/home/featured-blogs--homepage/acsm-blog/2020/03/30/exercise-immunity-covid-19-pandemic

15. Nieman DC, Wentz LM. The compelling link between physical activity and the body's defense system. J Sport Heal Sci. 2019;8(3):201-17.
16. Simpson RJ, Katsanis E. The immunological case for staying active during the COVID-19 pandemic. Brain Behav Immun [Internet]. 2020;(April):0-1. Available from: https://doi.org/10.1016/j.bbi.2020.04.041

17. Nieman DC, Henson DA, Austin MD, Sha W. Upper respiratory tract infection is reduced in physically fit and active adults. Br J Sports Med. 2011 Sep 1;45(12):987-92.

18. Kostka T, Berthouze SE, Lacour JR, Bonnefoy M. The symptomatology of upper respiratory tract infections and exercise in elderly people. Med Sci Sports Exerc. 2000;32(1):46-51.

19. Martin SA, Pence BD, Woods JA. Exercise and Respiratory Tract Viral Infections.

20. Organization WH. Supporting older people during the COVID-19 pandemic is everyone's business [Internet]. World Health Organization; 2020 [cited 2020 May 4]. Available from: http://www.euro.who.int/en/healthtopics/health-emergencies/coronavirus-covid-19/ news/news/2020/4/supporting-older-people-duringthe-covid-19-pandemic-is-everyones-business

21. Jiménez-Pavón D, Carbonell-Baeza A, Lavie CJ. Physical exercise as therapy to fight against the mental and physical consequences of COVID-19 quarantine: Special focus in older people. Prog Cardiovasc Dis. 2020;(xxxx):9-11.

22. Pollock RD, O’Brien KA, Daniels LJ, Nielsen KB, Rowlerson A, Duggal NA, et al. Properties of the vastus lateralis muscle in relation to age and physiological function in master cyclists aged 55-79 years. Aging Cell. 2018 Apr;17(2):e12735.

23. Bialek S, Gierke R, Hughes M, McNamara LA, Pilishvili T, Skoff T. Coronavirus Disease 2019 in Children - United States, February 12-April 2, 2020. MMWR Morb Mortal Wkly Rep [Internet]. 2020 Apr 10 [cited 2020 May 4];69(14):422-6. Available from: http://www. cdc.gov/mmwr/volumes/69/wr/mm6914e4.htm?s_ cid=mm6914e4_w

24. Radom-Aizik S. COVID-19, Exercise, Children and their Developing Immune System [Internet]. American College of Sports Medicine. 2020 [cited 2020 May 2]. Available from: https://www.exerciseismedicine.org/ support_page.php/stories/?b=899

25. World Health Organization. Global Recommendations on Physical Activity for Health [Internet]. 2010 [cited 2020 May 4]. Available from: https://www.who.int/dietphysicalactivity/publications/9789241599979/en/

26. Regular exercise benefits immunity -- even in isola- 
tion -- ScienceDaily [Internet]. [cited 2020 May 2]. Available from: https://www.sciencedaily.com/releases/2020/03/200331162314.htm

27. Turner J, Campbell JP. Regular exercise has long-term benefits for immunity - it's important to stay active [Internet]. The Conversation. 2020 [cited 2020 May 4]. Available from: https://theconversation.com/regularexercise-has-long-term-benefits-for-immunity-its-important-to-stay-active- 135836

28. Simpson RJ, Krüger K, Walsh NP, Campbell JP, Gleeson M, Nieman DC, et al. Can exercise affect immune function to increase susceptibility to infection? Exerc Immunol Rev. 2020;26:8-22.

29. David Oliver. Coronavirus: Don't exercise TOO much during quarantine. Here's why [Internet]. USA TODAY. 2020 [cited 2020 May 2]. Available from: https://www. usatoday.com/story/life/health-wellness/2020/04/30/ coronavirus-dont-exercise-too-much-during-quarantine-heres-why/3048034001/

30. Pedersen BK. Muscles and their myokines. J Exp Biol. 2011 Jan 15;214(2):337-46.

31. Steensberg A. The role of il-6 in exercise-induced immune changes and metabolism. Vol. 9, Exercise Immunology Review. 2003. p. 40-7.

32. Karstoft K, Pedersen BK. Exercise and type 2 diabetes: Focus on metabolism and inflammation. Immunology and Cell Biology. 2016.

33. Cerqueira É, Marinho DA, Neiva HP, Lourenço O. Inflammatory Effects of High and Moderate Intensity Exercise-A Systematic Review. Front Physiol [Internet]. 2020 Jan 9 [cited 2020 May 2];10:1550. Available from: https://www.frontiersin.org/article/10.3389/ fphys.2019.01550/full

34. Duggal NA, Niemiro G, Harridge SDR, Simpson RJ, Lord JM. Can physical activity ameliorate immunosenescence and thereby reduce age-related multi-morbidity? Nat Rev Immunol. 2019 Sep 1;19(9):563-72.

35. Adams GR, Zaldivar FP, Nance DM, Kodesh E, Radom-Aizik S, Cooper DM. Exercise and leukocyte interchange among central circulation, lung, spleen, and muscle. Brain Behav Immun. 2011 May 1;25(4):658-66.

36. Lancaster GI, Febbraio MA. The immunomodulating role of exercise in metabolic disease. Vol. 35, Trends in Immunology. Elsevier Ltd; 2014. p. 262-9.

37. Trochimiak T, Hübner-Woźniak E. Effect of exercise on the level of immunoglobulin a in saliva. Biol Sport. 2012;29(4):255-61.

38. Mohamed A, Alawna M. Role of increasing the aero- bic capacity on improving the function of immune and respiratory systems in patients with coronavirus (COVID-19): A review. Diabetes Metab Syndr Clin Res Rev [Internet]. 2020; Available from: https://doi. org/10.1016/j.dsx.2020.04.038

39. Booth FW, Roberts CK, Thyfault JP, Ruegsegger GN, Toedebusch RG. Role of inactivity in chronic diseases: Evolutionary insight and pathophysiological mechanisms. Vol. 97, Physiological Reviews. American Physiological Society; 2017. p. 1351-402.

40. Zhu W. Should, and how can, exercise be done during a coronavirus outbreak? An interview with Dr. Jeffrey A. Woods. J Sport Heal Sci. 2020;

41. İNAL İNCE D, VARDAR YAĞLI N, SAĞLAM M, ÇALIK KÜTÜKCÜ E. Yeni Tip Koronavirüs Kaynaklı COVID-19 (SARS-Cov-2) Enfeksiyonunda Akut Dönem ve Postakut Dönemde Fizyoterapi ve Rehabilitasyon. Türk Fiz ve Rehabil Derg [Internet]. 2020 Apr 17 [cited 2020 May 4];31(1):81-93. Available from: https://dergipark.org.tr/tr/doi/10.21653/tjpr.718877

42. Kurtaiş Aytür Y, Füsun KÖSEOĞLU B, Özyemişçi Taşkiran Ö, Kutay ORDU GÖKKAYA N, Ünsal Delialioğlu S, Sonel Tur B, et al. SARS-COV-2 (COVID-19) SONRASI PULMONER REHABİLITASYON PRENSIPLERİ: AKUT VE SUBAKUT SÜRECINN YÖNETIMII İÇİN REHBER. 2020.

43. Woods JA, Keylock KT, Lowder T, Vieira VJ, Zelkovich W, Dumich S, et al. Cardiovascular Exercise Training Extends Influenza Vaccine Seroprotection in Sedentary Older Adults: The Immune Function Intervention Trial. J Am Geriatr Soc. 2009;57(12):2183-91.

44. Kohl HW, Craig CL, Lambert EV, Inoue S, Alkandari JR, Leetongin G, et al. The pandemic of physical inactivity: Global action for public health. Lancet. $2012 \mathrm{Jul}$ 21;380(9838):294-305.

45. Staying Physically Active During the COVID-19 Pandemic [Internet]. World Health Organization. 2020. Available from: https://www.acsm.org/read-research/ newsroom/news-releases/news-detail/2020/03/16/ staying-physically-active-during-covid-19-pandemic

46. Hall G, Laddu DR, Phillips SA, Lavie CJ, Arena R. A tale of two pandemics: How will COVID-19 and global trends in physical inactivity and sedentary behavior affect one another? Prog Cardiovasc Dis. 2020;(xxxx):46. 